\title{
Review Article: \\ MANAGEMENT OF PERIOPERATIVE ANESTHESIA IN RIGHT HEART FAILURE
}

\author{
Fajar Perdhana, Herdono Purnomo \\ Department of Anesthesiology \& Reanimation, Faculty of Medicine, Universitas Airlangga, \\ Dr. Soetomo Hospital, Surabaya
}

\begin{abstract}
ABSTRAK
Disfungsi maupun gagal ventrikel kanan mendapat perhatian yang jauh lebih kecil dibandingkan dengan gagal ventrikel kiri. Disfungsi maupun gagal ventrikel kanan sangat berhubungan dengan peningkatan angka kematian baik pada kasus bedah jantung, kasus pembedahan selain bedah jantung maupun pada pasien-pasien yang dirawat di ICU. Tujuan dari review artikel ini untuk memaparkan anatomi, fisiologi dan patofisiologi terjadinya gagal fungsi ventrikel kanan, cara mendeteksi dan mendiagnosanya, serta pertimbangan penatalaksanaan dari sisi anestesi yang meliputi tahap preoperatif, intraoperatif dan postoperatif. Tindakan pembedahan jantung bisa berakibat pada gagal ventrikel kanan. Pada 0,1\% pasien post cardiotomy, misalnya, mengalami gagal jantung kanan yang berat dan membutuhkan support inotropik dalam jangka waktu yang lama, juga pada 2-3\% pasien paska transplantasi jantung, dan 20-30\% pasien yang diberikan alat bantu pada jantung kirinya. Oleh karena itu anestesiologis sangat berperan pada periode perioperatif maupun perawatan intensif paska operasi dan wajib mengerti serta memahami terjadinya disfungsi dan gagal ventrikel kanan sehingga mampu mendeteksi lebih dini, mencegah dan mengelola pasien dengan disfungsi ventrikel kanan. (FMI 2018;54:75-83)
\end{abstract}

Kata kunci: Gagal jantung kanan; manajemen perioperatif

\begin{abstract}
Right ventricular dysfunction and failure receive much less attention than the left ventricular failure. Right ventricular dysfunction or failure is associated with increased mortality rates in cardiac surgery, surgical cases other than cardiac surgery and also in patients treated in the ICU. The purpose of this article review was to describe the anatomy, physiology and pathophysiology of right ventricular failure, its detection and diagnosis, and management considerations from anesthetic point of view, including preoperative, intraoperative and postoperative stages. Cardiac surgery may result in right ventricular failure. For example, $0.1 \%$ post cardiotomy patients experience severe right heart failure and require long-term inotropic support, and so do 2-3\% of posttransplant patients, and 20-30\% of patients installed with instrument in his left heart. Therefore, anesthesiologists play a major role in perioperative and postoperative intensive care and are obliged to comprehend the nature of right ventricular dysfunction and failure so as to carry out early detection, prevent and manage patients with right ventricular dysfunction. (FMI 2018;54:75-83)
\end{abstract}

Keywords: Right heart failure; perioperative management

Correspondence: Fajar Perdhana, Dharmahusada Utara 3 No. 31, Surabaya, Indonesia. Phone: 081703450052.

Email: fajarperdhana@gmail.com

\section{INTRODUCTION}

Right ventricular dysfunction is strongly associated with increased mortality, either in cardiac surgery, noncardiac surgery, or in patients treated in the ICU. Right ventricular failure can occur before surgery, during surgery and post surgery. Post cardiac surgery may result in right ventricular failure. For example, $0.1 \%$ post cardiotomy patients experience severe right heart failure and require long-term inotropic support, and so do 2-3\% of post-transplant patients, and $20-30 \%$ of patients installed with instrument in his left heart (Denault et al 2013). However, right ventricular dysfunction and failure receive much less attention than the left ventricular failure. This results in delays to detect, prevent and deal with the failure of right ventricular function. Besides, the choice of therapy for right ventricular function failure is very limited (Forrest 2009). Therefore, an anesthesiologist, who play a role in the perioperative period and intensive care after surgery, has to understand right ventricular anatomy and physiology as well as the pathophysiology of the dysfunction and failure of the right ventricle. The purpose of this article review was to describe the anatomy, physiology and pathophysiology of right ventricular failure, its detection and diagnosis, and management considerations from anesthetic point of view, including preoperative, intraoperative and postoperative stages. 


\section{LITERATURE REVIEW}

\section{The definition}

Right ventricular failure (RVF) is defined as right ventricular inability to pump/allow adequate blood flow to the pulmonary circulation at normal central venous pressure (Greyson 2008). Whereas, according to Andre Yvan et al, right ventricular failure is a collection of symptoms and signs of persistent right ventricular dysfunction (RAP> $18 \mathrm{mmHg}$ with $\mathrm{CI}<2 \mathrm{~L} / \mathrm{min} / \mathrm{M} 2$ ) without elevated left atrial pressure/PCWP of $>18$ $\mathrm{mmHg}$, no pneumothorax, tamponade and ventricular arrhythmias (Denault et al 2013).

\section{Right ventricular anatomy}

The right ventricular anatomy is unique and complex. The size of the right ventricle is much smaller compared to the left ventricle, but the right ventricle volume is higher compared to the left ventricle. Based on MRI, right ventricular end-diastolic volume (RVEDV) is 49$101 \mathrm{~mL} / \mathrm{m} 2$ (in men $55-105 \mathrm{~mL} / \mathrm{m} 2$, in women $48-87$ $\mathrm{mL} / \mathrm{m} 2$ ) while left ventricular end-diastolic volume (LVEDV) is between $44-89 \mathrm{~mL} / \mathrm{m} 2$ (in men $47-92$ $\mathrm{mL} / \mathrm{m} 2$, in women $41-81 \mathrm{~mL} / \mathrm{m} 2)$. Right ventricular muscle mass is only one-sixth of the mass of the left ventricular muscle (Haddad et al 2009).

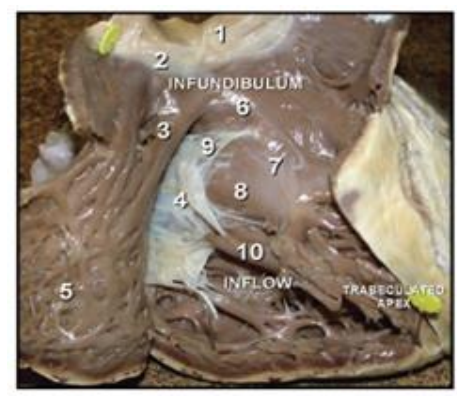

Fig. 1. Parts of the right ventricle.

There are 3 parts: inflow, apical trabecular, and infundibulum. 1. Pulmonary valve; 2 . Annulus pulmo-nary; 3. Supraventricular cortex; 4. Tricuspid valve; 5. Right anterior ventricle wall; 6 . Anterior portion of trabecula septal margin (TSM); 7. TSM body, 8. posterior section of TSM; 9. Chordae tendinea; 10. Anterior papillary muscles (Bertoja \& Lowery 2009).

Circulation in the right ventricle is more dominant supplied by right coronary artery (RCA). It is mainly found in approximately $70-80 \%$ of the population, and therefore it is commonly referred to as the right dominant perfusion. Upon exiting the aorta, the RCA runs along the AV groove (the gap between the right ventricle and the left ventricle, wrapping the AV groove and extend- ing until reaching the posterior wall and descending to the inferior portion toward the cardiac apex (Haddad et al 2008).

\section{Right ventricular physiology}

Under normal conditions, the stroke volume between the left and right ventricle is equal. However, since the right ventricle injects its volume into a low-resistance system, the right ventricle requires only one-fifth of the energy from the left ventricle. Therefore, the right ventricle has smaller and weaker period compared to the left ventricle. Since it is relatively weak, the right ventricle is unable to adapt acutely to the sudden increase of severe pulmonary vascular resistance (abrupt afterload) and this is what causes acute right heart failure. In contrast, the right ventricle has better compliance than the left ventricle, so it can accommodate venous return (preload) in large quantities (Bertoja \& Lowery 2009).

Fig. 2 shows that the right ventricle reaches its peak pressure early and decreases faster than the left ventricle pressure does. Uniquely, at the end of systole, there is still flow towards the pulmonary artery even though the right ventricular pressure gradient is negative and the pulmonary valve can close well after the right ventricle pressure begins to decrease. This is called "hangout interval" (Bertoja \& Lowery 2009).

Preload from the right ventricle is determined by the venous return and the distensibility of the right ventricle wall. The right ventricle is able to compensate for preload changes through stretching of the muscle wall without losing contractility (a dramatic increase in diastolic final volume is not followed by increased pressure at the diastolic end). When the critical point on the starling curve is skipped, right ventricular failure will occur (Greyson 2008, Kevin \& Barnard 2007).

Pulmonary circulation is the main determinant of right ventricular afterload. Pulmonary vascular bed is very compliant. It has low pressure and low resistance. In normal pulmonary circulatory conditions, energy needed in the right ventricle is only one-fifth of the left ventricle. There are several factors affecting the pulmonary vascular resistance (PVR), including hypoxia, hypercarbia, cardiac output, pulmonary pressure and volume and specific molecular pathways, e.g. nitric oxide pathway (vasodilatation), prostaglandin pathway (vasodilatation) and endothelin pathway (vasoconstriction). Pulmonary vasculature will have vasoconstriction during hypoxia and vasodilation during hyperoxia. Hypercarbia may cause severe vasoconstriction (Haddad et al 2009, Haddad et al 2008). 
Table 1. Structural and functional differences of right ventricle (RV) and left ventricle (LV) (Haddad et al 2008)

\begin{tabular}{|c|c|c|}
\hline Characterictics & RV & $\mathrm{LV}$ \\
\hline Structure & $\begin{array}{l}\text { Inflow region, tabeculated myocardium, } \\
\text { infundibulum }\end{array}$ & $\begin{array}{l}\text { Inflow region and myocardium, no } \\
\text { infundibulum }\end{array}$ \\
\hline Shape & $\begin{array}{l}\text { From the side: triangular } \\
\text { Cross section: cresentic }\end{array}$ & Ellipitic \\
\hline End-diastolic volume, $\mathrm{mL} / \mathrm{m} 2$ & $75 \pm 13(49-101)$ & $66 \pm 12(44-89)$ \\
\hline Thickness of ventricular wall, mm & 2 to 5 & 7 to 11 \\
\hline Ventricular pressure, $\mathrm{mmHg}$ & $25 / 4\{(15-30) /(1-7)\}$ & $130 / 8\{\{90-140 /(5-12)\}$ \\
\hline RVEF, \% & $\begin{array}{l}61 \pm 7(47-76) \\
>40-45\end{array}$ & $\begin{array}{l}67 \pm 5(57-78) \\
50\end{array}$ \\
\hline $\begin{array}{l}\text { Ventriculare elastance Emax, } \\
\mathrm{mmHg} / \mathrm{mL}\end{array}$ & $1.30+0.84$ & $5.48 \pm 1.23$ \\
\hline Compliance et end diastole, $\mathrm{mmHg}$ & Higher compliance than LV & $5.0 \pm 0.52 \times 10-2$ \\
\hline Filling profile & $\begin{array}{l}\text { Starts earlier and finishes later } \\
\text { Lower filling velocities }\end{array}$ & $\begin{array}{l}\text { Starts later and finishes earlier } \\
\text { Higher filling velocities }\end{array}$ \\
\hline PVR vs SVR dyne $\mathrm{s} \mathrm{cm}$ & $70(20-130)$ & $1100(700-1600)$ \\
\hline Stroke work index $\mathrm{g} / \mathrm{m} 2$ perbeat & $8 \pm 2(1 / 6$ of $\mathrm{LV}$ stroke work $)$ & $50 \pm 20$ \\
\hline Exercise reserve & $\uparrow \mathrm{RVEF} \geq 5 \%$ & $\uparrow L V E F \geq 5 \%$ \\
\hline Resistance to ischemia & Greater rescistance to ischemia & More susceptible to ischemia \\
\hline Adaptation to disease state & Better adaptation to volume overload state & Better adaptation to pressure overload state \\
\hline
\end{tabular}

Table 2. Differences of physiological parameters of right ventricle and left ventricle (Ganong 1993)

\begin{tabular}{lll}
\hline Parameters & Right ventricle & Left ventricle \\
\hline Stroke volume (rest) & $70-90 \mathrm{~mL}$ & $70-90 \mathrm{~mL}$ \\
Ejection fraction (rest) & Around 65\% & $70-80 \%$ \\
Tekanan ventrikel (diastole) & $0-8 \mathrm{mmHg}$ & $4-12 \mathrm{mmHg}$ \\
Tekanan ventrikel (sistole) & $15-30 \mathrm{mmHg}$ & $90-140 \mathrm{mmhg}$ \\
\hline
\end{tabular}

Another important factor of right ventricular afterload is ventricular interdependence, a concept describing that size, shape and compliance of a ventricle will affect other size, shape and volume-pressures correlation (Haddad et al 2008, 2009).

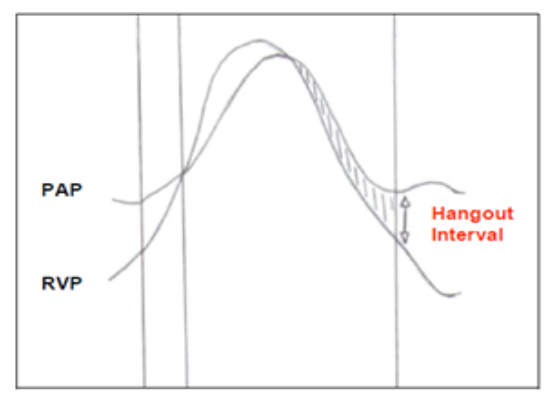

Fig. 2. Tracing of right ventricular pressure (Bertoja \& Lowery 2009). PAP (pulmonary artery pressure), RVP (right ventricular pressure).
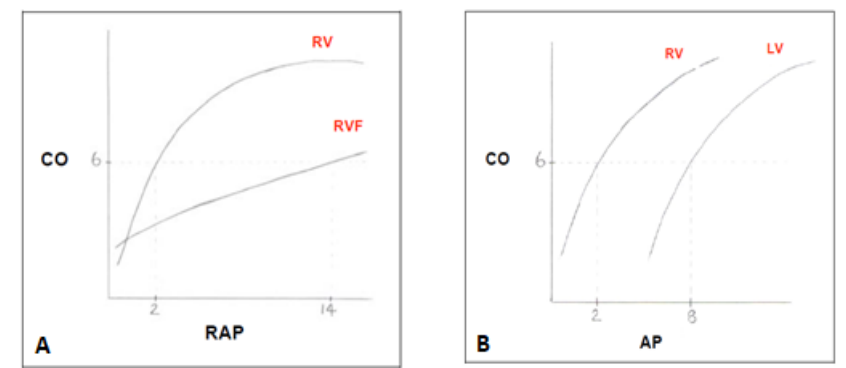

Fig. 3a. Frank Starling curve for right ventricle. 3b. Right and left ventricle differences, the left ventricle requires a larger atrial filling pressure to produce the same $\mathrm{CO}$ as the right ventricle (Bertoja \& Lowery 2009). CO (cardiac output), RAP (right atrial pressure), RV (right ventricular pressure), RVF (right ventricular failure). 
Table 3. Normal pressure (in mmHg) and pulmonary and systemic vascular resistance (Greyson 2010)

\begin{tabular}{lcc}
\hline & Systolic & Dyastolic \\
\hline Right ventricle & $15-25$ & $1-7$ \\
Pulmonary artery & & $8-12$ \\
Left ventricle & $90-140$ & $5-15$ \\
Aorta & & $60-90$ \\
Pulmonary vascular resistance dyne s cm -5 & $150-250$ & \\
Systemic vascular resistance & $900-1400$ & \\
Dyne s cm -5 & & \\
\hline
\end{tabular}

\section{Pathophysiology of right ventricular failure}

Table 4. Causes of right ventricular failure (RVF) (Haddad et al 2008)

\begin{tabular}{l}
\hline \multicolumn{1}{c}{ Causes } \\
\hline Right ventricle failure with normal afterload \\
Right ventricular infarction \\
Right ventricular failure secondary to increased afterload \\
Pulmonary embolism \\
Mitral valve disease with pulmonary hypertension \\
Congenital heart disease \\
ARDS \\
OSA (obstructive sleep apnea) \\
Increased afterload due to heart surgery complications \\
Inflammatory effects of CPB (cardiopulmonary bypass) \\
Protamine \\
Increased afterload due to thoracic surgery \\
Extensive lung resection \\
Use of left ventricle aids \\
Ventricular failure secondary to fluid overload \\
ASD and VSD
\end{tabular}

\section{Right ventricular response to acute pressure overload}

In physiological conditions, final systolic volume will be inversely proportional to systolic end pressure. Stroke volume will also increase when there is an increase in diastolic final volume. Right ventricular volume stroke will decrease dramatically compared to left ventricle when there is increased pressure during ejection. Laplace law can be used to explain the limitations of the right ventricle. 1) As the right ventricular wall is thinner, when right ventricular pressure increases, the ventricular wall stretch is increasing, 2) the radius of right ventricle curvature is increasing during contraction (while that of the left ventricle is decreasing). This means that the right ventricle does not have the ability to lower ventricular pressure during contraction by changing its shape (Greyson 2008, Bertoja \& Lowery 2009, Kevin \& Barnard 2007). Progressive right ventricular dilatation will increase interventricular septal shift to push the left ventricle and increase tricuspid regurgitation. Both right and left ventricle will lower the preload of the left ventricle. Cardiac output and pressure on the proximal aorta also decrease. The combination of decreased right coronary blood flow, decreased aortic proximal pressure and increased right ventricular pressure lead to right ventricular ischemia. Ischemia further causes right ventricular volume strokes, left ventricular preload and decreased MAP (Forrest 2009). Some conditions that cause pressure overload include left ventricular failure, pulmonary embolism, primary pulmonary hypertension, secondary pulmonary hypertension, pulmonary valve stenosis, and RVOT (right ventricular outflow tract) ob-struction (Bertoja \& Lowery 2009).

\section{Right ventricular response to chronic pressure overload}

Pressure in the right ventricle is normally higher than systemic pressure in fetus and neonates, but then drops within the first few days/weeks after birth. However, the right ventricle of the neonates can still tolerate ongoing pulmonary hypertension and patients with congenital 
heart disease may also tolerate much higher systemic pulmonary pressure for several years with limited ability (e.g. Eisenmenger's syndrome, TOF, Ebstein syndrome). In the case of chronic pressure overload, right ventricular hypertrophy will occur, which is likely to reduce stress due to overload pressure or even lead to contractility dysfunction of the right ventricle. However, the exact mechanism is still unclear (Greyson 2010).

\section{Right ventricular response to chronic volume overload}

Volume overload in the right ventricle is usually caused by regurgitation, e.g. tricuspid regurgitation, pulmonary valve regurgitation and may be due to ASD/VSD as well as anomalous pulmonary venous return disorder. Such volume overload condition due to intracardiac shunt can be well tolerated by the right ventricle because it has the ability to accommodate large volume changes.

According to the study, long-lasting volume overload does not impair the functioning of the right ventricular contractility. Patients with congenital heart disease with long-term volume overload may adapt to the condition for several years. However, in a condition where right ventricular dilatation is more severe, the addition of higher volume will disrupt left ventricular output due to interventricular shift. Acute right ventricular failure will occur when PVR increases. The afterload increases, so that the right ventricular contractility will decrease and haemodynamic collapse occurs (Greyson 2010, Kevin \& Barnard 2007).

\section{Right ventricular response to decreased contractility}

Severe and chronic right ventricular failure is usually tolerable if pulmonary driving pressure is preserved and PVR remains low, for example, in Fontan procedure for patients with single ventricle. Pulmonary driving pressure is mean pulmonary artery pressure (mPAP) substracted by left atrial pressure (LAP). mPAP is normally about $15 \mathrm{mmHg}$. Although the right ventricular contractility is absent, the pulmonary driving pressure can still be maintained by increasing the CVP, provided that mPAP and LAP remain low. However, if there is a slight increase in PVR in this situation, there will be haemodynamic collapse. It can therefore be concluded that right ventricular failure is a result of inadequate contractility, and volume or pressure overload (Greyson 2010).

\section{Pulmonary hypertension}

Under normal conditions, PVR is only $1 / 20$ of systemic resistance, and mean pulmonary artery pressure is not higher than central venous pressure. The $5 \mathrm{mmHg}$ pressure gradient alone along the pulmonary circulation is sufficient to maintain normal cardiac output under normal PVR conditions, normal left ventricular filling pressure and adequate right ventricular contractility (Greyson 2010, Kevin \& Barnard 2007). Pulmonary arterial pressure is the function of pulmonary vascular resistance, right ventricular cardiac output and right ventricular outflow pressure. Therefore, focusing on pulmonary artery pressure alone will obscure the etiology and potential therapeutic options for pulmonary hypertension (Greyson 2010).

Table 5. Revision of pulmonary hypertension classification, Venice 2003 (Kevin \& Barnard 2007)

\begin{tabular}{l}
\hline Pulmonary hypertension classification, Venice 2003 \\
\hline WHO group I: Pulmonary arterial hypertension (PAH) \\
Idiopathic (IPAH) \\
Familial (FPAH) \\
Associated with other disease (APAH): collagen vascular disease (eg. Scleroderma), congenital shunts between the systemic and \\
pulmonary circulation, portal hypertension, HIV infection, drugs, toxins, or other disease or disorders. \\
Associated with venous and capillary disease \\
\hline WHO group II: Pulmonary hypertension associated with left heart disease \\
Atrial or ventricular disease \\
Valvular disease (e.g., mitral stenosis) \\
\hline WHO group III: Pulmonary hypertension associated with lung disease and/or hypoxemia \\
Chronic obstructive pulmonary disease (COPD), interstitial lung disease (ILD) \\
Sleep-disordered breathing, alveolar hypoventilation \\
Chronic exposure to high altitude \\
Developmental lung abnormalities \\
\hline WHO group IV: pulmonary hypertension due to chronic thrombotic and/or embolic disease \\
Pulmonary embolism in the proximal or distal pulmonary arteries \\
Embolization of other matter, such as tumor cells or parasites \\
\hline WHO group V: miscellaneous
\end{tabular}


Group I PH is also referred to PAH (pulmonary arterial hypertension), which is $\mathrm{PH}$ that arises from anatomical and functional abnormalities of pulmonary vessels, including idiopathic pulmonary arterial hypertension or also called primary pulmonary hypertension. The underlying pathophysiology of $\mathrm{PH}$ in most cases of this type is mechanical obstruction to the bloodstream and this type is less responsive to vasodilators (Greyson 2010).

Group II PH is also called pulmonary venous hypertension, which is $\mathrm{PH}$ that arises from retrograde transmission due to the abnormal increase of pulmonary venous pressure for various reasons. Group II is largely secondary to abnormalities of the left ventricle, such as left ventricular systolic and diastolic dysfunction as well as mitral and aortic valve disease (Greyson 2010).

Groups III and IV are PH due to changes in the pulmonary pre-capillary arteriole. Secondary group III is due to lung disease or hypoxemia and at some point still considered normal due to response to external stimulation. Hypoxic pulmonary vasoconstriction causes V/Q mismatch, becoming pathological if many segments of the lung become hypoxic and the PVR rises too high. Group III can be improved by administering vasodilators, such as calcium channel blockers, direct pulmonary vasodilators, such as nitroprusside, and inhalation agents, such as nitric oxide. However, over time, the abnormality of this type III may become irreversible as in group I (Greyson 2010).

Group IV is when PH is caused by a blockage of the pulmonary artery or arteriole due to pulmonary embolism (either acute or chronic) and may be due to an embolic tumor. In the United States, the incidence of lung embolisms of 600,000 causes 60,000 deaths per year. Group V is PH with unknown causes and is unsuitable if incorporated into any of above categories (Greyson 2010).

\section{Perioperative evaluation}

Parameters to be observed include the assessment of the right atrium, right ventricular systolic function (at least one of the fractional area change (FAC), tricuspid annular plane systolic excursion (TAPSE), with or without RV index myocardial performance (RIMP), and systolic pulmonary artery pressure (sPAP) should also be measured by estimating right atrial (RA) pressure based on IVC size and collapsibility) (Rudski et al 2010).
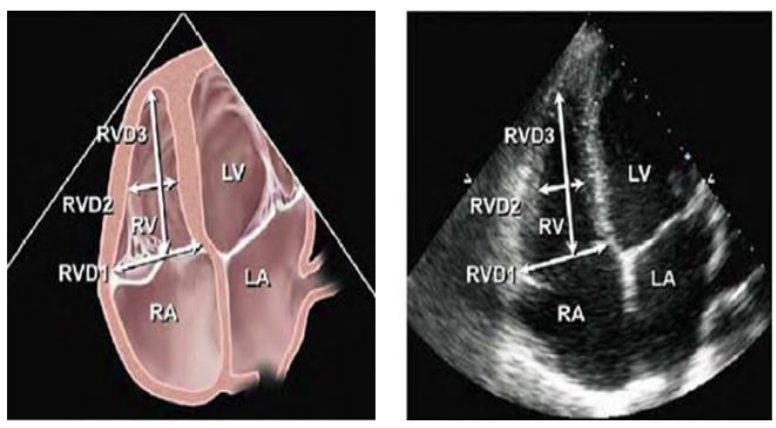

Figure 6. Apical 4 chamber (TTE).

RVD 1 = right ventricular basal dimension, RVD 2 = right ventricular midcavity dimension, RVD 3 = right ventricular longitudinal dimension.

TAPSE (Tricuspid Annular Plane Systolic Excursion) can be used for assessing right ventricular systolic function. TAPSE $<16 \mathrm{~mm}$ indicates the occurrence of right ventricular systolic dysfunction. Although it only assesses longitudinal function, it correlates well with other techniques used to assess the global function of the right ventricle. Another method is a two-dimensional FAC (fractional area change) that serves to estimate right ventricular systolic function in percentages. FAC $<35 \%$ indicates right ventricular systolic dysfunction (Greyson 2010).

Assessment of right ventricular diastolic function can be performed with pulsed doppler from tricuspid inflow, tissue doppler of lateral tricuspid annulus, pulsed doppler of hepatic vein, IVC diameter and collapsibility. The most recommended ones are the $\mathrm{E} / \mathrm{A}$ ratio, the deceleration time, the Ee 'ratio and the right atrium size. The above measurements are not valid if there is a significant TR. Tricuspid E/A ratio $<0.8$ indicates relaxation disturbance, a tricuspid E/A ratio of 0.8-2.1 with an E/e '>6 ratio or dominant diastolic flow in the hepatic vein indicate pseudonormal filling. The tricuspid E/A ratio >2.1 with deceleration time $<120 \mathrm{~ms}$ indicates restrictive filling(Rudski et al 2010).

\section{Systolic pulmonary artery pressure (SPAP)/right ventricular systolic pressure (RVSP)}

The speed of tricuspid regurgitation (TR velocity) can be used to measure RVSP by adding RA pressure in case of absent significant RVOT obstruction. RA pressure can be obtained from IVC and collapsibility values as described above. In general, TR velocity $>2.8$ - 2.9 represents SPAP of about $36 \mathrm{mmHg}$, assuming a normal RA pressure of about 3-5 $\mathrm{mmHg}$ (Rudski et al 2010). 
RVSP can also be determined using the Bernouli equation: $\mathrm{RVSP}=4(\mathrm{~V}) 2+\mathrm{RA}$ pressure. $\mathrm{V}$ is the peak velocity (in meters per second) of TR regurgitation jet, and RA pressure is determined from IVC diameter and collapsibility as described above (Rudski et al 2010). Normal value of SPAP is defined as the peak of gradient $\mathrm{TR}=2.8-2.9 \mathrm{~m} / \mathrm{s}$ or peak systolic pressure 35-36 $\mathrm{mmHg}$, assuming RA pressure of 3-5 mmHg. According to the latest AHA consensus, $\mathrm{PH}$ is defined when RVSP>40 mmHg. Some cardiologists call severe PH if SPAP $>2 / 3$ systemic systolic blood pressure (Rudski et al 2010).

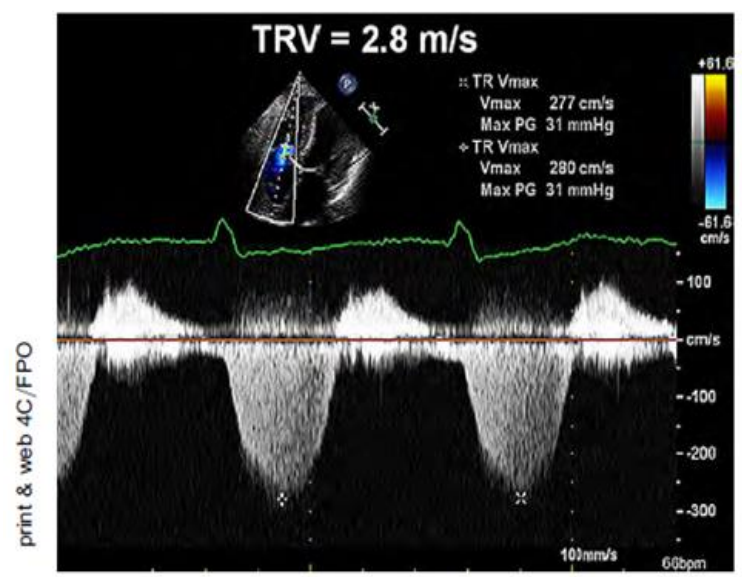

Fig. 7. Doppler echo to determine SPAP.

The spectrum of tricuspid regurgitation doppler signal represents pressure gradient RA and RV. SPAP is calculated by summing RAP (RA pressure) with peak pressure gradient between the peak of the right ventricle and the apex of the right atrium. For example, the calculation of SPAP is $31+\mathrm{CVP}=34 \mathrm{mmHg}$, assummed that CVP is $3 \mathrm{mmHg}$ (Rudski et al 2010).

The administration of pulmonary vasodilator therapy should be planned in patients with severe IPM. Longterm therapy of IPM should be maintained in perioperative period. In previously untreated patients, pulmonary vasodilators should be considered to reduce the adverse effects of perioperative factors that may increase PVR. Sildenafil, bosentan, or intravenous prostacycline administration should begin several months or weeks before elective surgery, in which the response of the illoprost can be assessed immediately before induction of anesthesia. Therapeutic response (decreased PVR) will lead to decreased CVP and increased CO. In patients with severe right ventricular dysfunction, PAP will not decrease significantly (due to increased cardiac output) (Greyson 2010).
There is not really adequate data to support management to prevent perioperative decompensation in patients at risk of right ventricular failure. However, ventilation factors that cause elevated PVR should be avoided, such as hypoventilation and hypercapnea that may increase PAP, hypoxia that may cause pulmonary vasoconstriction, atelectasis, and high-pressure ventilation, as it may lead to right ventricular dilatation, septal shift interventricular and decrease right ventricular output (Forrest 2009).

In patients with poor respiratory function, it will be difficult to prevent hypoxia, hypoventilation and atelectasis when we minimize the ventilation pressure provided. If ventilation control is required, the best PEEP (Positive End Expiratory Pressure) can be given from the lowest inflection point of the respiratory volumepressure relation curve, preferably low volume tidal but with faster breathing frequency. Lower ventilation pressure is easier to obtain with spontaneous breath, but PEEP and pressure support should still be given to prevent atelectasis and hypoventilation (Grey-son, 2010).

\section{Anesthesia option}

The option of anesthesia aministration should be able to maintain RV preload, RV contractility, minimize PVR and avoid RV hypoperfusion due to decreased MAP. Therefore, if neuraxial technique is the option, the drugs administered should be gradual using invasive monitoring, and vasopressor agents should be readily available (Greyson 2010).

The depth of anesthesia and postoperative analgesia should be sufficient to prevent large sympathetic and haemodynamic responses due to pain and surgery, especially in patients with severe IPM and right ventri-cular dysfunction. Both general and anesthetic techni-ques have been used successfully in patients with high risk of right ventricular decompensation, for example patients with severe PHT performed cesarean section (Greyson 2010).

\section{Inhalation anesthesia}

All volatile anesthesia may aggravate RV dysfunction by decreasing preload, afterload and contractility. Halothane, enflurane, isoflurane and sevoflurane do not affect PVR. However, PVR will increase with desflurane and $\mathrm{N} 2 \mathrm{O}$ administration. Therefore, both agents should be avoided in patients with the risk of right ventricular decompensation (Greyson 2010). 
Table 6. Summary of recommendations for patients with the risk of right ventricular decompensation (Forrest 2009)

\begin{tabular}{|c|c|c|c|}
\hline Intervension & RVF without PHT & Severe PHT without RVF & Severe PHT + RVF \\
\hline \multicolumn{4}{|l|}{ Premedication } \\
\hline Sildenafil 25-50 mg po & - & - & + \\
\hline \multicolumn{4}{|l|}{ Preinduction } \\
\hline Iloprost $(10 \mathrm{mcg})$ nebul & - & $+/-$ & + \\
\hline \multicolumn{4}{|l|}{ Monitoring } \\
\hline CVP, Spontaneous ventilation & - & - & - \\
\hline IPPV & + & + & + \\
\hline Invasive $\mathrm{BP}$; spontaneous ventilation & - & - & + \\
\hline IPPV & + & - & + \\
\hline \multicolumn{4}{|l|}{ PAC (or other CO monitoring) } \\
\hline Spontaneous ventilation & - & - & + \\
\hline IPPV & - & - & \\
\hline TOE & $+/-$ & - & $+/-$ \\
\hline Neuraxial Anestesia & + & + & + \\
\hline \multicolumn{4}{|l|}{ Ventilation } \\
\hline High FiO2 & + & + & + \\
\hline Mild hyperventilation & + & + & + \\
\hline Low ventilation pressure & + & + & + \\
\hline \multicolumn{4}{|l|}{ Anesthetic agents } \\
\hline Ketamin, in infants and children & + & + & + \\
\hline Ketamin, in adults & $+/-$ & - & - \\
\hline Thiopentone/etomidate & + & + & + \\
\hline Propofol & + & + & - \\
\hline $\mathrm{N} 2 \mathrm{O}$ & - & - & - \\
\hline Isoflurane/halothane/enflurane & + & + & + \\
\hline Desflurane & - & - & - \\
\hline Fentanyl/sufentanyl/remifentanyl & + & + & + \\
\hline
\end{tabular}

\section{Intravenous anesthesia}

The preferred induction agent for patients with RV dysfunction is etomidate. Thiopentone decreases RV and SVR contractility but does not affect PVR. Keta-mine will increase PVR in adult patients, but not infant or children with IPM. In patients with respiratory failure, propofol infusion decreases RV contractility, but can be resisted by dobutamine. The right ventricular function is more susceptible to propofol infusion compared to isoflurane in cardiac surgery patients, but the opposite condition occurs in patients with one-lung ventilation. The explanation of this contradiction is that propofol may increase the effects of endogenous pulmonary vasodilators under certain conditions. For example, propofol normally has no effect on PVR, but with alpha adrenoceptor activation will produce pulmonary vasoconstriction (Greyson 2010).

\section{Opiate}

Fentanyl and sufentanyl have minimal effect on pulmonary hemodynamics. Remifentanil causes mild pulmonary vasodilation mediated by histamine release and opiate receptor pathways (Greyson 2010).

\section{Monitoring of right ventricular function}

Acute right ventricular failure should be suspected when CVP is high and cardiac output is low. Other resembling causes, such as pneumothoracic and high PEEP, should be excluded clinically. Echocardiography is needed to distinguish right ventricular dysfunction with other causes, such as cardiac tamponade. Pulmonary artery catheter is very useful for monitoring the right ventricle function. Acute PAP increase is an early sign of increased pulmonary vascular resistance (PVR), in which acute right ventricular failure is characterized by increased CVP and decreased CO. Increased PVR will increase PAP, right heart contractility will also increase right ventricular $\mathrm{CO}$. When the right ventricular contraction is weak, there will be a decrease in PAP and an increase in CVP, which is a sign of right heart failure. The key to management under these conditions is the therapeutic response of the inhaled pulmonary vasodilator, not the decrease in PAP, but the decrease in CVP and increase in CO (Greyson 2010).

When right heart failure is suspected, then general supportive modalities should be provided while waiting for echocardiographic evaluation. Supportive modalities that can be given include $100 \%$ oxygen, ventilation op- 
timization (hypoventilation correction/minimize air-way pressure) and hypotension therapy with vaso-pressor. Intravenous fluids should be discontinued. In patients with acute RV failure or previously already suffering from RV failure, the purpose of the therapy is to prevent RV ischemia, optimize RV preload, afterload and contractility, and maintain systemic hemodynamics (Greyson 2010).

Table 7. Summary of pharmacological therapy for perioperative right ventricular failure (Grey-son 2010)

\begin{tabular}{lcc}
\hline & Normal PVR & High PVR \\
\hline Vasolidator pulmoner & & \\
NO (110 ppm) & - & + \\
Iloprost (10 mcg neb) & - & + \\
Milrinone (2-5 mg neb) & - & + \\
Sildenafil (50 mg po) & - & + \\
Vasopressor & & \\
Phenylephrine & + & + - \\
Noradrenaline & + & + \\
Vasopressin & + & + \\
Inotrops & & + \\
Dobutamin & + & + \\
Adrenaline & + & + \\
Milrinone & + & + \\
Levosimendan & + & + \\
\hline
\end{tabular}

\section{CONCLUSION}

Right ventricle has a function that is not less important to the left ventricle function. The right ventricle is not a weak left ventricle. It differs from the left ventricle in terms of geometry, the structure of the muscle fibers, the conduction system, the coronary flow as well as the role in the interventricular interaction. Important aspects of right ventricular protection in patients with perioperative decompensation risk are prevention, early detection and appropriate management to counter the underlying pathophysiology. Minimizing PVR and maintaining MAP are important points to do to prevent right ventricular decompensation characterized by increased CVP and decreased cardiac output. Although there is no solid data in its management strategy, the combination of milanone or mild irrontinous oralino-prophic inhalation with oral sildenafil will result in a decrease in PVR, without interfering with SVR. Early detection of risk factors both through clinical and supported by echocardiography, proper perioperative monitoring and proper postoperative care will reduce morbidity and mortality rates due to right ventricular decompensation.

\section{REFERENCES}

Bertoja E, Lowery J (2009) Right heart physiology. Anesthesia Tutorial of The Week 130, 1-8

Denault AY, Haddad F, Jacobsohn E, Deschamp A (2013). Perioperative right ventricular dysfunction. Curr Opin Anesthesiol 26, 1-11

Forrest P (2009). Anaesthesia and right ventricular failure. Anaesthesia and Intensive care 37, 370-83

Greyson CR (2008). Pathofisiology of right ventricular failure. Critical Care Medicine 36, S57-65

Greyson CR (2010). The right ventricle and pulmonary circulation: basic concepts. Rev Esp Cardiol 63, 81-95

Haddad F, Couture P, Tousignant C, Denault AY (2009). The right ventricle and cardiac surgery, a perioperative perspective: I. anatomy, physiology, and assessment. Anesthesia and Analgesia 108, 407-21

Haddad F, Hunt SA, Rosenthal DN, Murphy DJ (2008). Right ventricular function in cardiovascular disease, part I: anatomy, physiology, aging and functional assessment of the right ventricle. Circulation 117, 1436-48

Kevin LG, Barnard M (2007). Right ventricular failure. British Journal of Anaesthesia 7, 89-94

Rudski LG, Lai WW, Afilalo J, Hua L, Handschumacher MD, Chandrasekaran K, et al (2010). Guidelines for the echocardiographic assessment of the right heart in adults: a report from the american society of echocardiography. J Am Soc Echocardiogr 23, 685713 